\title{
INTRODUCTION OF THE METHOD OF HARMONIC WEIGHTS AND INTEGRATED ECONOMIC AND STATISTICAL CALCULATIONS IN THE ANALYSIS OF SOCIO-ECONOMIC SECURITY
}

\author{
CShvaiba D., ORCID: 0000-0001-6783-9765, Ph.D., \\ Belarusian Trade Union of workers of chemical, mining and oil industries, \\ Belarusian national technical University, Minsk, Belarus, shvabia@tut.by

\section{ВНЕДРЕНИЕ МЕТОДА ГАРМОНИЧЕСКИХ ВЕСОВ И УКРУПНЕННЫХ ЭКОНОМИКО-СТАТИСТИЧЕСКИХ РАСЧЕТОВ ПРИ АНАЛИЗЕ ПОКАЗАТЕЛЕЙ СОЦИАЛЬНО-ЭКОНОМИЧЕСКОЙ БЕЗОПАСНОСТИ}

\author{
СШвайба Д. Н., ORCID: 0000-0001-6783-9765, канд. экон. наук, \\ Белорусский профсоюз работников химической, горной и нефтяной отраслей \\ промышленности, Белорусский начиональный технический университет, \\ 2. Минск, Беларусь, shvabia@tut.by
}

Abstract. In the implementation of comparative analysis of the application of methods of harmonic weights and integrated economic and statistical calculations in the analysis of socioeconomic security characteristics, the priority is given to the method of integrated economic and statistical calculations. When predicting the characteristics of socio-economic security by the method of integrated economic and statistical calculations, their absolute levels or the dynamics of their growth are used. The use of the absolute values of socio-economic security characteristics in forecasting seems more appropriate, as it is possible to solve a number of problems of the method — to identify the levels of factors and factors $\mathrm{K}_{-} \mathrm{xi}$ in the lead period.

Аннотащия. При реализации сравнительного анализа применения методов гармонических весов и укрупненных экономико-статистических расчетов при анализе характеристик социально-экономической безопасности приоритет отдан методу укрупненных экономико-статистических расчетов. При прогнозировании характеристик социально-экономической безопасности методом укрупненных экономико-статистических расчетов применяются их абсолютные уровни либо динамика их роста. Использование при прогнозировании абсолютных значений характеристик социально-экономической безопасности видится более целесообразным, т. к. представляет возможность решить ряд проблем метода - выявить уровни факторов и коэффициентов $\mathrm{K}$ х хі в периоде упреждения.

Keywords: socio-economic security, government, society, enterprise, employee, threat, security, interests, economics, analysis, system.

Ключевые слова: социально-экономическая защищенность, государство, общество, предприятие, работник, угроза, защищенность, интересы, экономика, анализ, система.

When creating a predictive model using the harmonic weights method, the subsequent time series levels are assigned greater weights compared to the previous ones [1-3]. 
Time series of levels of socio-economic security characteristics $Y_{t}(\mathrm{t}=1,2, \ldots, \mathrm{n})$ divided into 2ve components

$$
Y_{t}=\varphi(t)+\varepsilon_{t}
$$

where: $\varphi(\mathrm{t})$ - a function of the time trend

$\varepsilon_{\mathrm{t}}$ - random component.

With the help of the constructed model, forecast values are calculated $Y_{t}$ and forecast error in the period $\alpha_{(\mathrm{li})} \mathrm{S}_{\mathrm{w}}$ in $(\mathrm{t}+1)$ period $(\mathrm{l}=1,2, \ldots, \mathrm{L})$.

Let us consider the method of formation of the forecast model by the method of harmonic weights based on the forecast of the number of threats (Table 1.).

Table 1.

DYNAMICS OF THE NUMBER OF THREATS IN T-8-T YEARS

\begin{tabular}{cccccccccc}
\hline Years & $t-8$ & $t-7$ & $t-6$ & $t-5$ & $t-4$ & $t-3$ & $t-2$ & $t-1$ & $t$ \\
\hline Threats & 218 & 233 & 255 & 287 & 335 & 403 & 498 & 610 & 762 \\
$\mathrm{t}$ & 1 & 2 & 3 & 4 & 5 & 6 & 7 & 8 & 9 \\
\hline
\end{tabular}

Source: elaboration of author

Using the least squares method, we calculate the exponents of the equations of linear segments, taking the length of the period $(\mathrm{k})$ equal to 5 .

Table 2.

INTERMEDIATE CALCULATIONS

FOR CALCULATING THE TREND PARAMETERS OF THE 1ST SEGMENT

\begin{tabular}{cccccc}
\hline № & Year & $Y$ & $t$ & $Y_{t}$ & $t^{2}$ \\
\hline 1 & $\mathrm{t}-8$ & 218 & 1 & 218 & 1 \\
2 & $\mathrm{t}-7$ & 233 & 2 & 466 & 4 \\
3 & $\mathrm{t}-6$ & 255 & 3 & 765 & 9 \\
4 & $\mathrm{t}-5$ & 287 & 4 & 1148 & 16 \\
5 & $\mathrm{t}-4$ & 335 & 5 & 1675 & 25 \\
$\Sigma$ & --- & 1328 & 15 & 4272 & 55 \\
\hline
\end{tabular}

Source: elaboration of author

The system of normal equations will have the form:

$$
\begin{gathered}
\left\{\begin{array}{c}
1328=5 \alpha_{0}+15 \alpha_{1} \\
4272=15 \alpha_{0}+55 \alpha_{1}
\end{array} \mid-3\right. \\
\left\{\begin{array}{c}
-3984=-15 \alpha_{0}-45 \alpha_{1} \\
4272=15 \alpha_{0}+55 \alpha_{1} \\
288=10 \alpha_{1} ; \alpha_{1}=28,8
\end{array}\right. \\
\alpha_{0}=\frac{1328-15 \times 28,8}{5}=179,2
\end{gathered}
$$


INTERMEDIATE CALCULATIONS

Table 3 .

FOR CALCULATING THE TREND PARAMETERS OF THE 2ND SEGMENT

\begin{tabular}{cccccc}
\hline № & Year & $Y$ & $t$ & $Y_{t}$ & $t^{2}$ \\
\hline 1 & $\mathrm{t}-7$ & 233 & 2 & 466 & 4 \\
2 & $\mathrm{t}-6$ & 255 & 3 & 765 & 9 \\
3 & $\mathrm{t}-5$ & 287 & 4 & 1148 & 16 \\
4 & $\mathrm{t}-4$ & 335 & 5 & 1675 & 25 \\
5 & $\mathrm{t}-3$ & 403 & 6 & 2418 & 36 \\
$\Sigma$ & --- & 1513 & 20 & 6472 & 90 \\
\hline
\end{tabular}

Source: elaboration of author

$$
\alpha_{0}=134,6 ; \alpha_{1}=42
$$

Trend parameters for all phases of the moving trend are also calculated.

The number of equations is revealed by the formula:

$$
\begin{gathered}
\mathrm{n}-\mathrm{k}+1=9-5+1=5 \\
Y_{1}(t)=179,2+28,8 t(t=1,2,3,4,5) \\
Y_{2}(t)=134,6+42,0 t(t=2,3,4,5,6) \\
Y_{3}(t)=54,6+60,2 t(t=3,4,5,6,7) \\
Y_{4}(t)=-58,8+80,9 t(t=4,5,6,7,8) \\
Y_{5}(t)=-221,1+106,1 t(t=5,6,7,8,9)
\end{gathered}
$$

Using these equations, the values of the moving trend are calculated $Y_{j(t)}$ :

in points $\mathrm{t}=1$ and $\mathrm{t}=9$ mychelleusa 1 -the value $\bar{Y}_{1(t)}$ and $\bar{Y}_{9(t)}$;

in points $\mathrm{t}=2$ and $\mathrm{t}=8-$ value $\bar{Y}_{2(t)}$ and $\bar{Y}_{8(t)}$ mychelleusa 2 -um values $Y_{2}(t)$ and $Y_{8}(t)$ etc.

$$
\begin{gathered}
\bar{Y}_{1(t)}=179,2+28,8 \times 1=208 \\
\bar{Y}_{2(t)}=\frac{(179,2+28,8 t)+(134,4+42,0 t)}{2}=\frac{(179,2+28,8 \times 2)+(134,6+42,0 \times 2)}{2}=227,7
\end{gathered}
$$

In the following, we also substitute the corresponding value $t$ into the corresponding number of models:

$$
\begin{aligned}
& \bar{Y}_{3(t)}=\frac{(179,2+28,8 \times 3)+(134,6+42,0 \times 3)+(54,6+60,2 \times 3)}{3}=253,8 \\
& \overline{\mathrm{Y}}_{4(\mathrm{t})}=\frac{(179,2+28,8 \times 4)+(134,6+42,0 \times 4)+(54,6+60,2 \times 4)}{4}+\frac{(-58,8+80,9 \times 4)}{4}=289,3 \\
& \bar{Y}_{5(t)}=\frac{(179,2+28,8 \times 5)+(134,6+42,0 \times 5)+(54,6+60,2 \times 5)}{5} \\
& +\frac{(-58,8+80,9 \times 5)+(-221,1+106,1 \times 5}{5}=335,7 \\
& \bar{Y}_{6(t)}=\frac{(134,6+42,0 \times 4)+(54,6+60,2 \times 4)}{4}+\frac{(-58,8+80,9 \times 6)+(-221,1+106,1 \times 6)}{4} \\
& =411,125 \\
& \bar{Y}_{7(t)}=\frac{(54,6+60,2 \times 7)}{3}+\frac{(-58,8+80,9 \times 7)+(-221,1+106,1 \times 7)}{3}=501,7 \\
& \bar{Y}_{8(t)}=\frac{(-58,8+80,9 \times 8)+(-221,1+106,1 \times 8)}{2}=608,05 \\
& \bar{Y}_{9(t)}=-221,1+106,1 \times 9=733,8
\end{aligned}
$$


Based on these values $\bar{Y}_{j(t)}$ calculate the gains by the formula:

$$
\begin{gathered}
\omega_{t+1}=\bar{Y}_{t+1}-\bar{Y}_{t} \\
\omega_{2}=227,7-208,0=19,7 \\
\omega_{3}=253,8-227,7=26,1 \\
\omega_{4}=289,3-253,8=35,5 \\
\omega_{5}=335,7-289,3=46,4 \\
\omega_{6}=411,125-335,7=75,425 \\
\omega_{7}=501,7-411,125=90,575 \\
\omega_{8}=608,05-501,7=106,35 \\
\omega_{9}=733,8-608,05=125,75
\end{gathered}
$$

The average growth is calculated by the formula

$$
\overline{\bar{\omega}}=\sum_{t=1}^{n-1} C_{t+1}^{n} \omega_{t+1}
$$
weights.

where $C_{t+1}^{n}$ - the coefficients, giving follow-up information compared with the previous large

Они должны удовлетворять следующим условиям:

$$
\begin{gathered}
C_{t+1}^{n}>0(\mathrm{t}=1,2, \ldots, \mathrm{n}-1) \\
\sum_{t=1}^{n-1} C_{t+1}^{n}=1
\end{gathered}
$$

Coefficients $C_{t+1}^{n}$ calculated by dividing the harmonic weights by n-1. Harmonic weights $m_{j}$ calculated by the formula:

$$
m_{t+1}=m_{t}+\frac{1}{n-t},(t=2,3, \ldots, n-1)
$$

In this case, for a point $t=2$

$$
\begin{gathered}
m_{2}=\frac{1}{n-1}=\frac{1}{9-1}=0,125 \\
m_{3}=m_{2}+\frac{1}{n-2}=0,125+\frac{1}{9-2}=0,268 \\
m_{4}=m_{3}+\frac{1}{n-3}=0,268+\frac{1}{9-3}=0,435 \\
m_{5}=m_{4}+\frac{1}{n-4}=0,435+\frac{1}{9-4}=0,635 \\
m_{6}=m_{5}+\frac{1}{n-5}=0,635+\frac{1}{9-5}=0,885 \\
m_{7}=m_{6}+\frac{1}{n-6}=0,885+\frac{1}{9-6}=1,218 \\
m_{8}=m_{7}+\frac{1}{n-7}=1,218+\frac{1}{9-7}=1,718 \\
m_{9}=m_{8}+\frac{1}{n-8}=1,718+\frac{1}{9-8}=2,718
\end{gathered}
$$

In practice, statistical tables of harmonic weights are often used [4] (Table 5.). 
After calculating the value of the harmonic weights, we calculate $C_{t+1}^{n}$

$$
\begin{aligned}
& C_{2}=\frac{0,125}{8}=0,0156 \\
& C_{3}=\frac{0,268}{8}=0,0335 \\
& C_{4}=\frac{0,435}{8}=0,0544 \\
& C_{5}=\frac{0,635}{8}=0,0794 \\
& C_{6}=\frac{0,885}{8}=0,1106 \\
& C_{7}=\frac{1,218}{8}=0,1522 \\
& C_{8}=\frac{1,718}{8}=0,2147 \\
& C_{9}=\frac{2,718}{8}=0,3397
\end{aligned}
$$

In that case:

$$
\begin{gathered}
\overline{\bar{\omega}}=\sum_{\mathrm{t}=1}^{\mathrm{n}-1} \mathrm{C}_{\mathrm{t}+1}^{\mathrm{n}} \omega_{\mathrm{t}+1}=94,4752 \\
19,7^{*} 0,0156=0,3073 \\
23,1^{*} 0,0335=0,8744 \\
35,5^{*} 0,0544=1,9312 \\
46,4^{*} 0,0794=3,6842 \\
75,425^{*} 0,1106=8,3420 \\
90,575^{*} 0,1522=13,7855 \\
106,35^{*} 0,2147=22,8333 \\
125,75^{*} 0,3397=42,7173 \\
----------------- \\
94,4752
\end{gathered}
$$

Value $S_{w}$ can be defined by the formula:

$$
\begin{gathered}
\mathrm{S}_{\mathrm{w}}=\sqrt{\sum_{\mathrm{t}=1}^{\mathrm{n}-1} C_{\mathrm{t}+1}^{\mathrm{n}}\left(\omega_{\mathrm{t}+1}-\overline{\bar{\omega}}\right)^{2}}=\sqrt{1021,55}=31,9617 \\
0,0156 \times(19,7-94,4752)^{2}=87,2247 \\
0,0335 \times(26,1-94,4752)^{2}=156,6181 \\
0,0544 \times(35,5-94,4752)^{2}=189,2072 \\
0,0794 \times(46,4-94,4752)^{2}=183,5112 \\
0,1106 \times(75,425-94,4752)^{2}=40,1378 \\
0,1522 \times(90,575-94,4752)^{2}=2,3152 \\
0,2147 \times(106,35-94,4752)^{2}=30,2750 \\
0,3397 \times(125,75-94,4752)^{2}=332,2650 \\
1021,554
\end{gathered}
$$

The value of $\alpha$ (1) is calculated by the formula:

$$
\alpha(\mathrm{l})=\alpha \sum_{\mathrm{t}=1}^{\mathrm{n}-1} \mathrm{C}_{\mathrm{t}+1}^{\mathrm{n}}(\mathrm{l}=0,1, \quad 2, \ldots, \mathrm{n}-1)
$$


$\alpha$ for this example, take 4 .

$$
\begin{gathered}
\alpha\left(\mathrm{l}_{1}\right)=(0,3397+0,2147) \times 4=2,2176 \\
\alpha\left(\mathrm{l}_{2}\right)=(0,3397+0,2147+0,1522) \times 4=2,8264 \\
\alpha\left(\mathrm{l}_{3}\right)=(0,3397+0,2147+0,1522+0,1106) \times 4=3,2688 \\
\alpha\left(\mathrm{l}_{4}\right)=(0,3397+0,2147+0,1522+0,1106+0,0794) \times 4=3,5864 \\
\alpha\left(\mathrm{l}_{4}\right)=(0,3397+0,2147+0,1522+0,1106+0,0794+0,0544) \times 4=3,8040
\end{gathered}
$$

To calculate the highest and lowest variants of the equations of socio-economic security are calculated $\alpha\left(\mathrm{l}_{1}\right) \mathrm{S}_{\mathrm{w}}$

$$
\begin{gathered}
\alpha\left(l_{1}\right) S_{w}=2,2176 \times 31,9617=70,8783 \\
\alpha\left(l_{2}\right) S_{w}=2,8264 \times 31,9617=90,3365 \\
\alpha\left(l_{3}\right) S_{w}=3,2688 \times 31,9617=104,4764 \\
\alpha\left(l_{4}\right) S_{w}=3,5864 \times 31,9617=114,6274 \\
\alpha\left(l_{5}\right) S_{w}=3,8040 \times 31,9617=121,5823
\end{gathered}
$$

\begin{tabular}{|c|c|c|c|c|c|c|c|c|}
\hline Years & $t$ & $Y_{t+1}^{*}$ & $\bar{\omega}$ & $l$ & $\alpha(l)$ & $\alpha(l) S_{w}$ & $\begin{array}{l}\overline{Y^{*}} t+l \\
+\alpha(l) S_{w}\end{array}$ & $\begin{array}{l}\overline{Y^{*}} t+l \\
-\alpha(l) S_{w}\end{array}$ \\
\hline$t+1$ & 10 & 828,2752 & 94,4752 & 1 & 2,2176 & 70,8783 & 899,153 & 757,3969 \\
\hline$t+2$ & 11 & 922,750 & 94,4752 & 2 & 2,8264 & 90,3365 & 1013,086 & 832,4139 \\
\hline$t+3$ & 12 & 1017,225 & 94,4752 & 3 & 3,2688 & 104,4764 & 1121,701 & 912,749 \\
\hline$t+4$ & 13 & 1111,700 & 94,4752 & 4 & 3,5864 & 114,6274 & 1226,327 & 997,073 \\
\hline$t+5$ & 14 & 1206,176 & 94,4752 & 5 & 3,8040 & 121,5823 & 1327,758 & 1084,593 \\
\hline
\end{tabular}

Forecast levels of socio-economic security are calculated by the formula:

$$
\begin{gathered}
{\overline{Y^{*}}}_{t+1}={\overline{Y^{*}}}_{t}+\overline{\bar{\omega}}=733,8+94,4752=828,2752 \\
\overline{Y^{*}}{ }_{t+2}={\overline{Y^{*}}}_{t+1}+\overline{\bar{\omega}}=828,2752+94,4752=922,7504 \\
{\overline{Y^{*}}}_{t+3}={\overline{Y^{*}}}^{t+2}+\overline{\bar{\omega}}=922,7504+94,4752=1017,225 \\
{\overline{Y^{*}}}_{t+5}={\overline{Y^{*}}}^{t+4}+\overline{\bar{\omega}}=1111,700+94,4752=1206,176 \\
{\overline{Y^{*}}}_{t+4}={\overline{Y^{*}}}_{t+3}+\overline{\bar{\omega}}=1017,225+94,4752=1111,700
\end{gathered}
$$

The largest and smallest options for ensuring socio-economic security [5] are calculated by the formulas:

$$
\begin{gathered}
\overline{Y^{*}}{ }_{n+1}-\alpha(l) S_{w} \\
\overline{Y^{*}}{ }_{n+1}+\alpha(l) S_{w} \\
{\overline{Y^{*}}}_{t+1}-\alpha\left(l_{1}\right) S_{w}=828,2752-70,8783=757,3969 \\
\overline{Y^{*}}{ }_{t+2}-\alpha\left(l_{2}\right) S_{w}=922,7504-90,3365=832,4139 \\
\overline{Y^{*}}{ }_{t+3}-\alpha\left(l_{3}\right) S_{w}=1017,225-104,4764=912,749 \\
\overline{Y^{*}}{ }_{t+4}-\alpha\left(l_{4}\right) S_{w}=1111,700-114,6274=997,073 \\
\overline{Y^{*}}{ }_{t+5}-\alpha\left(l_{5}\right) S_{w}=1206,176-121,5823=1084,593 \\
{\overline{Y^{*}}}_{t+1}+\alpha\left(l_{1}\right) S_{w}=828,2752+70,8783=899,153 \\
{\overline{Y^{*}}}_{t+2}+\alpha\left(l_{2}\right) S_{w}=922,7504+90,3365=1013,086 \\
{ }_{Y^{*}}{ }_{t+3}+\alpha\left(l_{3}\right) S_{w}=1017+104,4764=1121,701 \\
\overline{Y^{*}}{ }_{t+4}+\alpha\left(l_{4}\right) S_{w}=1111,700+114,6274=1226,327 \\
\overline{Y^{*}}{ }_{t+5}-\alpha\left(l_{5}\right) S_{w}=1206,176+121,5823=1327,758
\end{gathered}
$$

The obtained forecast indicators are formed in the table (Table 4.).

Table 4.

FORECASTED VALUE ${\overline{Y^{*}}}_{t+l},{\overline{Y^{*}}}_{t+l} \pm \alpha(l) S_{w}$ 
Based on Table 4. we build a graph of the dynamics of actual and forecast data of indicators of socio-economic security in $t+1 \div t+5$ years

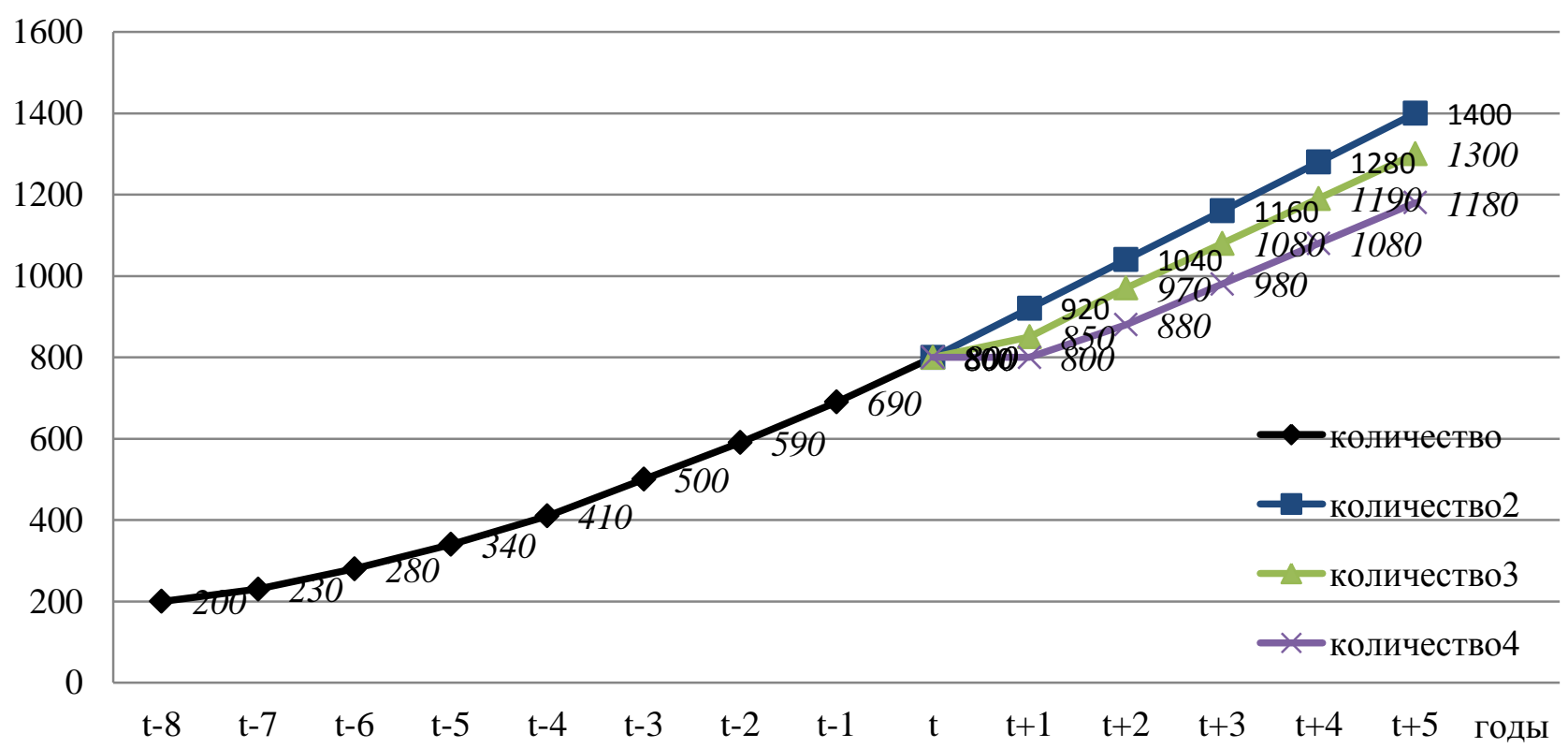

Graph 1. Dynamics of actual and forecast levels of socio-economic security in the $t+8 \div t+5$ years. Source: elaboration of author

- actual levels of socio-economic security in the $t+8 \div t$ years;

- forecast levels of socio-economic security in the $t+8 \div t+5$ years.

At the same time, the method of integrated economic and statistical calculations is based on the study of numerical relations between the data of socio-economic security and their extrapolation in the forecast period [6-8]. Predictive models will look like:

$$
Y_{t j}=K_{i j} \times X_{i}
$$

where: Y-forecast levels of an effective indicator of socio-economic security; j-options (minimum, medium and maximum);

$X_{i}$ - factors (economic, social, etc., indicators) $(\mathrm{i}=1, \ldots, \mathrm{n})$ );

$\mathrm{t}$ - the forecast to year forecast period;

1-years of lead time $(1=1, \ldots, \mathrm{L})$.

When forecasting socio-economic security data by the method of integrated economic and statistical calculations, their absolute levels or the dynamics of their growth are used. The use of absolute data in forecasting indicators of socioeconomic security seems more appropriate because it is possible to solve a number of problems of the method to identify the levels of factors and coefficients $K_{x i}$ in the lead period.

In the form of factors in the forecast models, it makes sense to include any necessary indicators of socio-economic security that affect the value of the resulting indicator. The detection of their levels in the period of pre-emption occurs with the help of trend models, methods of exponential smoothing, methods of harmonic weights, etc.

The calculation of the coefficient levels can be a certain difficulty $K_{x i}$ in the lead period. 
긴

a

ก

$\underline{\infty}$

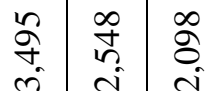

工

$\underline{-}$

n

$\pm$

\section{$m$}

|

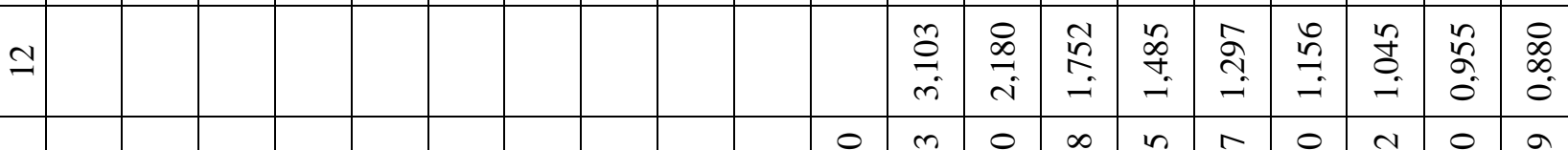

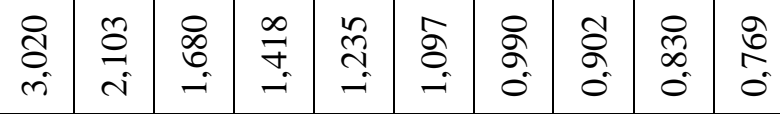

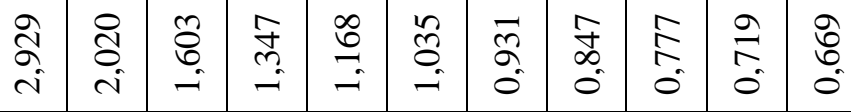

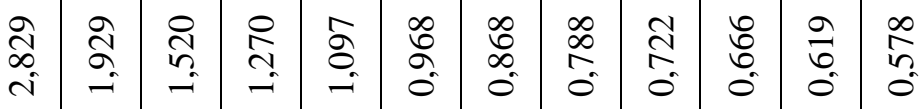

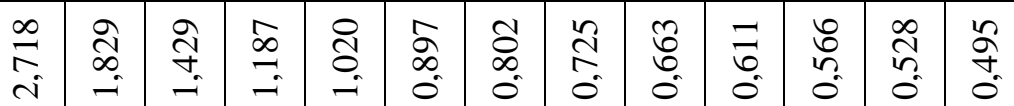

r

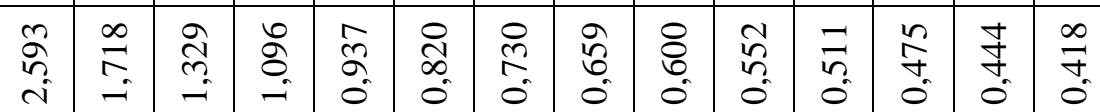

6

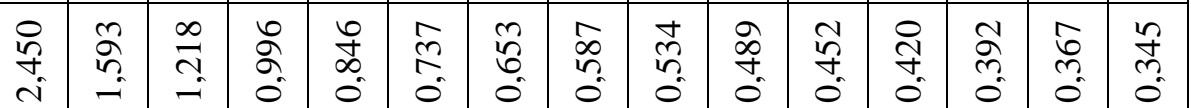

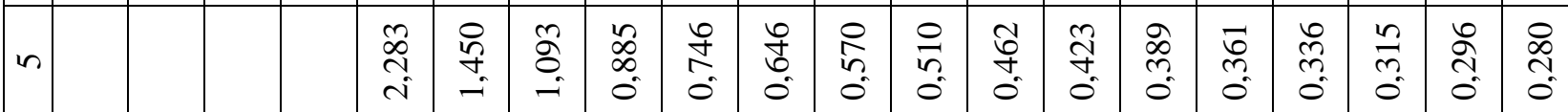

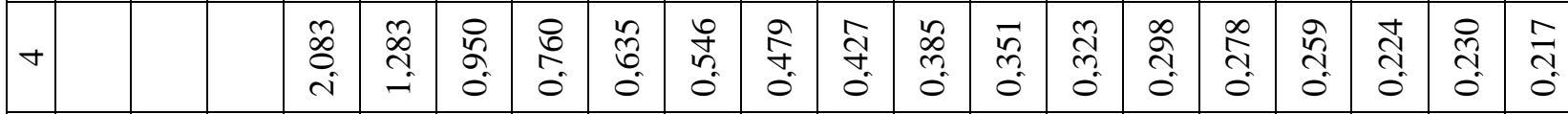

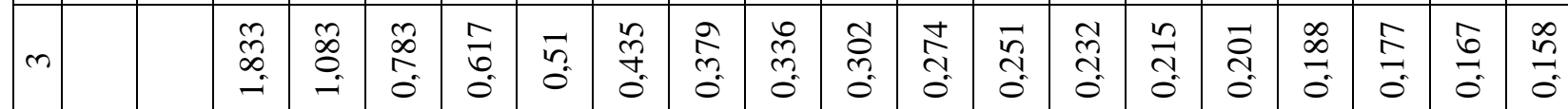

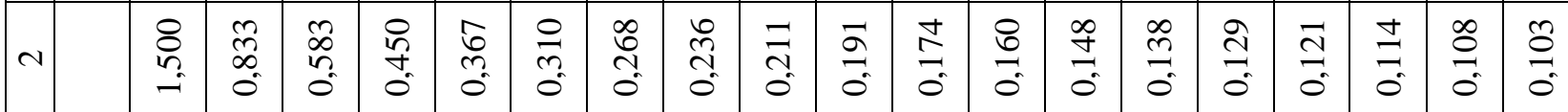

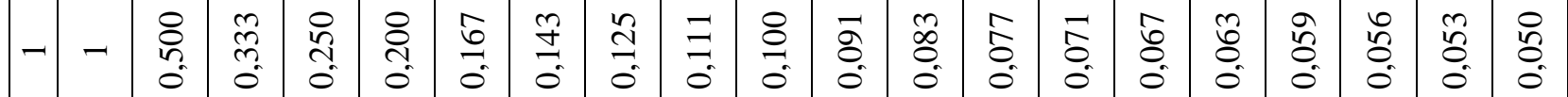

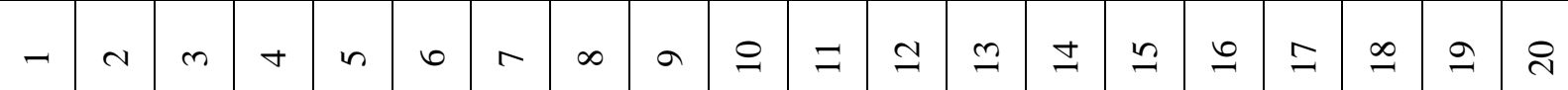


Based on the theory in the time series of coefficients characterizing the ratio of the resulting indicator of socio-economic security to the factors of each year of the retrospective period, the level of coefficients can be constant (approximately constant) or in their series there will be a tendency to increase (decrease) [8]. In the 1st case (the level of coefficients in the pre-forecast period is stable) when searching for the level of coefficients in the period of anticipation of difficulties does not occur (their level in the forecast period will be taken equal to the level in the retrospective period). In a situation where there is a clear tendency to increase and there are no cycles in the time series of these coefficients when their level is found during the lead time, it makes sense to apply the following approach:

a) set the value and value of the difference between each subsequent and previous coefficient $K_{x i}$ (the value of "plus" is inherent in time series of coefficients with a tendency to increase, "minus" — with a tendency to decrease);

b) by dividing the sum of the increments of the coefficients by the number of these increments, calculate the average annual change in the level of the coefficients $\Delta K_{x i}$ in the retrospective period;

c) by summation with the level of the coefficient $K_{x i}$ in the last year of the retrospective period of its average annual change, we obtain the level of this coefficient in the 1 st year of the lead period.

d) as a result of such iterations (point "b") we find the level of coefficients characterizing the ratio of the level of socio-economic security to the levels of factors in each year of the lead period, in other cases (the presence of cycles, it is difficult to identify any pattern in the change in the coefficients, etc.) it is necessary to apply individual or group expert assessments.

When calculating the minimum and maximum level of coefficients $K_{x i}$ we will proceed from the proposal that the ratio of the levels of the resulting indicator of socio-economic security and the factors in the lead-up period can not be lower than achieved, i.e. the level of the coefficient $K_{x i}$ in each year of the lead-time period, the ratio may not be lower than in the last year (s) of the retrospective period. Naturally, this premise is conditional, since the presence of time series of coefficients should be allowed from the theory $K_{x i}$ with dynamics to reduction. But in the long-term forecasting factors, in the time series of which the coefficients $K_{x i}$ they tend to decrease, it is impractical to apply, due to the fact that there may come a moment $t$, in which a logical interpretation of the revealed result will be impossible. In this regard, it seems reasonable to use in determining $K_{x i} \max K_{x i} \min$ the following approach:

- consider the level $K_{x i}$ min in the final year of the pre-emption period corresponding to the level of this coefficient in the final year of the retrospective period;

- consider the level $K_{x i} \max$ equal to the sum of the level $K_{x i}$ and maximum value $K_{x i}$ in the pre-forecast period.

To study trends in time series of socio-economic security characteristics, factors and coefficients $K_{x i}$ it is necessary to apply the primary information for a longer period.

$$
\begin{gathered}
\Delta K_{x 1}=\frac{0,070+0,080+0,071+0,078}{4}=0,075 \\
\Delta K_{x 2}=0,038 \quad \Delta K_{x 3}=0,002
\end{gathered}
$$


Table 6.

PRIMARY INFORMATION TO IDENTIFY PREDICTIVE OPTIONS FOR INCREASING

SOCIO-ECONOMIC SECURITY BY THE METHOD

OF INTEGRATED ECONOMIC AND STATISTICAL CALCULATIONS

\begin{tabular}{ccccccc}
\hline Year & $K_{x 1}$ & $\Delta K_{x 1}$ & $K_{x 2}$ & $\Delta K_{x 2}$ & $\Delta K_{x 3}$ & $K_{x 3}$ \\
\hline t-4 & 1,151 & & 2,029 & & 1,857 & \\
t-3 & 1,221 & 0,070 & 2,069 & 0,040 & 1,858 & 0,001 \\
t-2 & 1,301 & 0,080 & 2,120 & 0,051 & 1,861 & 0,003 \\
t-1 & 1,372 & 0,071 & 2,152 & 0,032 & 1,864 & 0,003 \\
t & 1,450 & 0,078 & 2,183 & 0,031 & 1,865 & 0,001 \\
\hline
\end{tabular}

Source: elaboration of author

The predictive model of coefficients $K_{x i}(t+l)$ will have the form $K_{x i}(t+l)=K_{x i}(t)+$ $\Delta K_{x i} t$, where $\mathrm{t}+1$ - year of lead periothe $\mathrm{d}(\mathrm{l}=1, \ldots$ the, $\mathrm{L})$.

Then:

$$
\begin{gathered}
K_{x 1}(t+l)_{\min }=1,450 \\
K_{x 1}(t+l)_{c p}=1,450+0,075 t \\
K_{x 1}(t+l)_{\max }=1,450+0,082 t \\
K_{x 2}(t+l)_{\min }=2,183 \\
K_{x 2}(t+l)_{c p}=2,183+0,038 t \\
K_{x 2}(t+l)_{\max }=2,183+0,051 t \\
K_{x 3}(t+l)_{\min }=1,865 \\
K_{x 3}(t+l)_{c p}=1,865+0,002 t \\
K_{x 2}(t+l)_{\max }=1,865+0,0031 t
\end{gathered}
$$

Predictive models to identify the minimum, average and maximum options for the characteristics of socio-economic security, formed by the method of integrated economic and statistical calculations, will have the form:

$$
\begin{gathered}
Y_{\min }=\sqrt[3]{1,450 x \times 2,183 x_{2} \times 1,865 x_{3}} \\
Y_{c p}=\sqrt[3]{(1,450 x+0,075 t) \times x_{1}(2,183+0,038 t) \times x_{2}(1,865+0,02 t) \times x_{3}} \\
Y_{\text {max }}=\sqrt{(1,450 x+0,0805 t) \times x_{1}(2,183+0,051 t) \times x_{2}(1,865+0,003 t) \times x_{3}}
\end{gathered}
$$

where: $\mathrm{t}$ for the 1 -year period of pre-emption equal to 1.

Limits of mathematical nature to the selection of factors included in the model, the method of integrated economic and statistical calculations does not show, in connection with which different options for the selection of factors are possible $[10 ; 11]$.

When implementing a comparative analysis of the application of methods of harmonic weights and integrated economic and statistical calculations in the analysis of socio-economic security characteristics, the priority is given to the method of integrated economic and statistical calculations. When forecasting the characteristics of social and economic security by the method of integrated economic and statistical calculations, their absolute levels or the dynamics of their 
growth are used. Use in predicting the absolute values of the characteristics of the socio-economic security see more appropriate because it is possible to solve a number of problems of the method to identify the levels of factors and coefficients $\mathrm{K}_{\mathrm{xi}}$ in the lead period.

\section{References:}

1. Kil'dishev, G. S., \& Frenkel', A. A. (1973). Analiz vremennykh ryadov i prognozirovanie. Moscow: Statistika. 103.

2. Darmoyan, P. A., \& Kuchevskii, N. G. (1975). Metody prognozirovaniya passazhirskikh perevozok. Minsk: Nauka i tekhnika. 85.

3. Trukhov V. A., Chindarev V. V. Metod garmonicheskikh vesov. Brest. 1994. 325.

4. Frenkel' A. A. Matematicheskie metody analiza dinamiki i prognozirovaniya proizvoditel'nosti truda. M.: Ekonomika, 1972. $190 \mathrm{s.}$

5. Klimuk V. V., Klimuk E. V. Sotsial'no-ekonomicheskii vektor bezopasnosti gosudarstva v napravlenii ratsional'nogo importozameshcheniya // Vestnik Samarskogo gosudarstvennogo ekonomicheskogo universiteta. 2016. № 2 (136). S. 28-33.

6. Maksimov G. T. Metodika faktornogo analiza i planirovaniya proizvoditel'nosti truda $\mathrm{v}$ promyshlennosti. Minsk: Belarus', 1978. $141 \mathrm{~s}$.

7. Borshchevskii I. I., Trukhov V. A. Proizvoditel'nost' truda: metody analiza i prognozirovaniya. Minsk: Nauka i tekhnika. 1988. $140 \mathrm{~s}$.

8. Vishnevskii A. A. Ekonomicheskaya bezopasnost' i sovremennyi vzglyad na ee doserzhanie // Trud. Profsoyuzy. Obshchestvo. 2017. №3 (57). S. 55-58.10. Shvaiba, D. (2019). Dynamic regression models of forecasting indicators of social and economic security. Bulletin of Science and Practice, 5(1), 249-257.

9. Shvaiba, D. (2019). Dynamic regression models of forecasting indicators of social and economic security Bulletin of Science and Practice, 5(1). 249-257.

10. Shvaiba, D. (2018). Socio-economic security of the hierarchical system. Bulletin of Science and Practice, 4(6), 248-254.

\section{Список литературь:}

1. Кильдишев Г. С., Френкель А. А. Анализ временных рядов и прогнозирование. М.: Статистика. 1973. 103 с.

2. Дармоян П. А., Кучевский Н. Г. Методы прогнозирования пассажирских перевозок. Минск: Наука и техника. 1975.85 с.

3. Трухов В. А., Чиндарев В. В. Метод гармонических весов. Брест. 1994. 325 с.

4. Френкель А. А. Математические методы анализа динамики и прогнозирования производительности труда. М.: Экономика, 1972. 190 с.

5. Климук В. В., Климук Е. В. Социально-экономический вектор безопасности государства в направлении рационального импортозамещения // Вестник Самарского государственного экономического университета. 2016. № 2 (136). С. 28-33.

6. Максимов Г. Т. Методика факторного анализа и планирования производительности труда в промышленности. Минск: Беларусь, 1978. 141 с.

7. Борщевский И. И., Трухов В. А. Производительность труда: методы анализа и прогнозирования. Минск: Наука и техника. 1988. 140 с.

8. Вишневский А. А. Экономическая безопасность и современный взгляд на ее досержание // Труд. Профсоюзы. Общество. 2017. №3 (57). С. 55-58.

9. Shvaiba D. Dynamic regression models of forecasting indicators of social and economic security // Бюллетень науки и практики. 2019. Т. 5. №1. С. 249-257. 
10. Shvaiba, D. Socio-economic security of the hierarchical system // Бюллетень науки и практики. 2018. Т. 4. №6. С. 248-254.

Работа поступила

в редакциию 17.02.2019 2.
Принята к публикациии 21.02.2019 2.

Cite as (APA):

Shvaiba, D. (2019). Introduction of the method of harmonic weights and integrated economic and statistical calculations in the analysis of socio-economic security. Bulletin of Science and Practice, 5(3), 250-261. https://doi.org/10.33619/2414-2948/40/31.

Ссылка для циитирования:

Shvaiba D. Introduction of the method of harmonic weights and integrated economic and statistical calculations in the analysis of socio-economic security // Бюллетень науки и практики. 2019. T. 5. №3. C. 250-261. https://doi.org/10.33619/2414-2948/40/31. 